\title{
Dietary habits and selenium, glutathione peroxidase and total antioxidant status in the serum of patients with relapsing-remitting multiple sclerosis
}

Katarzyna Socha ${ }^{{ }^{*}}$, Jan Kochanowicz ${ }^{2,3}$, Elżbieta Karpińska ${ }^{1}$, Jolanta Soroczyńska', Marta Jakoniuk³, Zenon Mariak² and Maria H Borawska'

\begin{abstract}
Background: Dietary habits and adequate dietary intake of antioxidants in the diet may be one of the most important environmental factors for the prevention of Multiple Sclerosis (MS).

Objectives: The aim of this study was to estimate selenium (Se) concentration, glutathione peroxidase (GSH-Px) activity and total antioxidant status (TAS) in the serum of patients with MS and the influence of dietary habits on the status.

Methods: 101 patients with relapsing-remitting MS (aged 18-58 years), as well as control group of 63 healthy people (aged 19-65 years) were studied. Food-frequency questionnaires were implemented to collect the dietary data. Se concentration in the serum samples was determined by atomic absorption spectrometry. GSH-Px activity and TAS in examined serum was measured using the ready-made sets of tests by Randox Laboratories Ltd., UK.

Results: Serum Se concentration and GSH-Px activity in the serum of patients with MS $(55.2 \pm 16.2 \mu \mathrm{g} / \mathrm{L}$, $6676.1 \pm 2386.4 \mathrm{U} / \mathrm{L}$; respectively) were significantly decreased $(\mathrm{p}<0.01, p<0.05$; respectively) compared with control group $(79.2 \pm 20.6 \mu \mathrm{g} / \mathrm{L}, 8029.9 \pm 2650.1 \mathrm{U} / \mathrm{L}$; respectively). A significant correlation $(r=0.39, p<0.01)$ was observed between Se concentration and GSH-Px activity in the serum of examined patients. TAS value in the serum of patients with MS $(1.03 \pm 0.37 \mathrm{mmol} / \mathrm{L})$ was also significantly lower $(p<0.01)$ than in healthy volunteers $(1.48 \pm 0.41 \mathrm{mmol} / \mathrm{L})$. Frequent consumption of poultry, bakery products, pulses and fish seemed to increase serum Se concentration in the group of patients; whereas frequent consumption of butter, wholegrain bread, sweet beverages and sugar was found to accompany with lower values of Se in the serum. We have observed significant decrease TAS $(p<0.05, p<0.01$; respectively) in the serum of smokers and those patients who received immunomodulatory drugs $(0.95 \pm 0.39 \mathrm{mmol} / \mathrm{L}, 0.92 \pm 0.34 \mathrm{mmol} / \mathrm{L}$; respectively) compared with no-smoking patients and not taking immunomodulators $(1.14 \pm 0.33 \mathrm{mmol} / \mathrm{L}, 1.31 \pm 0.31 \mathrm{mmol} / \mathrm{L}$; respectively).

Conclusions: Serum Se concentration, GSH-Px activity and TAS value were significantly lower in patients with relapsing-remitting MS compared with healthy volunteers. Dietary habits have a significant influence on Se status. Smoking cigarettes and intake of immunomodulatory drugs therapy have a negative impact on TAS of examined patients.
\end{abstract}

Keywords: Multiple sclerosis, Selenium, Glutathione peroxidase activity, Total antioxidant status, Dietary habits, Smoking cigarettes

\footnotetext{
*Correspondence: katarzyna.socha@umb.edu.pl

'Department of Bromatology, Medical University of Bialystok, Mickiewicza 2D

St, Bialystok 15-222, Poland

Full list of author information is available at the end of the article
} 


\section{Background}

Multiple Sclerosis (MS) is an inflammatory demyelinating disease of the central nervous system that may result in a wide range of neurological symptoms and accumulating disability. The exact pathophysiology of MS is not clear but it seems to be autoimmune in nature [1]. Haider et al. have demonstrated an important role of oxidative damage in the pathogenesis of demyelination and neurodegeneration in MS [2]. According to some data also diet can contribute to the development of MS - high-calorie, high-protein, high in fat and sugars can promote MS, whereas low-calorie can reduce the risk $[3,4]$.

Poor dietary selenium (Se) intake and status have been shown to be associated with an elevated risk for various diseases. Key role of $\mathrm{Se}$ in human metabolism is attributed to its presence in the glutathione peroxidase (GSH-Px) - an antioxidant enzyme which protects cells against harmful effects of free radicals. Se has an immunostimulant and anti-inflammatory effect [5] and it is highly dependent on dietary sources. The north-eastern region of Poland is an area of low Se concentration in soil, and the population is subjected to a particularly high risk of low Se status [6]. All antioxidants in the body (both enzymatic and non-enzymatic) form a total antioxidant status of an individual. Miller et al. defined total antioxidant status (TAS) as the sum of endogenous and food derived antioxidants of the extracellular fluid of an individual. Cooperation of all different antioxidants provides greater protection against reactive oxygen and nitrogen radicals than any single compound alone [7]. The aim of this study was to evaluate serum Se concentration, GSH-Px activity, and TAS value of patients with MS as well as the influence of dietary habits and smoking cigarettes on the status.

\section{Methods}

One hundred and one patients with relapsing-remitting MS between the ages of 18 - 58 (with an average age of $40.86 \pm 10.2$ years) who were under the care of the NZOZ Kendron in Bialystok, were enrolled in the study. Patients eligible for the study were met the McDonald criteria for a diagnosis of MS and had a relapsing clinical course $[8,9]$. According to a 10-point scale EDSS (Extended Disability Status Scale) in examined patients the median was 3,5 (inter-quartile range $2-4$ points). The average duration of disease was $5,44 \pm 5.2$ years (range $1-23$ years). 65\% of patients received immunomodulatory drugs (interferon beta, fingolimod, natalizumab, glatiramer acetate). The blood was drawn in remission and as the recent relapse of the disease has passed from least eight months to six years, patients were not treated with corticosteroids. Control blood samples were drawn from 63 healthy volunteers in comparable age (19-65 years, an average age of $41.12 \pm 14.1$ years) and gender to the study group. The blood from the control group was collected in the same period as the study group (from 2011 until 2013). Patients and control group data are shown in (Table 1).

Food-frequency questionnaires were implemented to collect the dietary data. Patients with MS were asked to complete the questionnaire of the Committee of Human Nutrition Science, Polish Academy of Sciences, concerning the frequency of food products consumption. The list of food commodities is consist of 36 food items (white bread, wholegrain bread, sweets, cereal products, grain products, pulses, milk, cottage cheese, other sorts of cheese, meat, poultry, offal, sausages, ham, meat products, bacon, tinned meat, tinned fish, fresh fish, eggs, butter, margarine, vegetable oils, potatoes, processed vegetables, fresh vegetables, fruit, sugar added to beverages, marmalade, honey, soft drinks, beer, wine, vodka, coffee, tea). The consumption frequency of different kind of food was estimated according to the following criteria: frequent consumption was defined as an intake of certain food products from twelve to thirty days per month, except fish, that was eaten four to twelve times a month. Food products eaten less frequently were classified into "sporadic consumption" group [10].

Blood samples were drawn from patients and control group were drawn using the vacutainer system test tubes containing clot activator (Becton Dickinson, France). The samples were allowed to clot within 30 minutes then centrifuged within 10 minutes at approximately $1000 \times$ g. Serum was removed and kept frozen at $-20^{\circ} \mathrm{C}$. The protocol of the study was approved by the Local Ethical Committee (R-I-002/70/2011) and written consent was taken from every participant.

The concentration of Se in the serum was determined by the electrothermal atomic absorption spectrometry method with Zeeman background correction (Z-2000 instrument, Hitachi, Japan). Determine the concentration of Se, TAS and GSH-Px in the tested samples were taken during the month. Every day, certified reference material of human serum (Seronorm Trace Elements, Serum Level 1, 0903106, Sero AS, Norway) was used to test the accuracy of this method. The results of the quality control

Table 1 Patients and control group characteristic

\begin{tabular}{lcc}
\hline Variable & $\begin{array}{c}\text { Patients with MS } \\
(\mathbf{n}=\mathbf{1 0 1})\end{array}$ & $\begin{array}{c}\text { Control group } \\
(\mathbf{n}=\mathbf{6 3})\end{array}$ \\
\hline Gender (M/F) & $37 / 64$ & $20 / 43$ \\
Age (years) - Mean (range) & $40.86 \pm 10.2(18-58)$ & $41.12 \pm 14.1(19-65)$ \\
Smoking/No-smoking* & $45 / 56$ & $26 / 37$ \\
Immunomodulatory drugs & $52 / 49$ & $0 / 63$ \\
therapy (yes/no) & & \\
\hline
\end{tabular}

$\mathrm{M}$ - male, $\mathrm{F}$ - female; * number of cigarettes: 5-20/daily. 
analyses corresponded with the reference values. The accuracy of the method was $0.28 \%$ and the coefficient of variation was $1.6 \%$. The detection limit of the method was $1.49 \mu \mathrm{g} / \mathrm{L}$. The Department of Bromatology, Medical University of Bialystok participates in a quality control program for trace element analysis supervised by the National Institute of Public Health - National Institute of Hygiene and the Institute of Nuclear Chemistry and Physics. GSH-Px activity and TAS in the serum was measured using the ready-made sets of tests by Randox Laboratories Ltd. (United Kingdom) and UV - VIS spectrophotometer (Cintra 3030, GBC, Australia).

Statistical analyses were performed using Statistica v.10.0 software. Differences between independent groups were tested by the Mann-Whitney U-test. Correlation was calculated by Spearman rank test. To estimate the influence of dietary habits on the Se status in the examined patients, we used a multiple linear regression analysis.

\section{Results}

Se concentration and GSH-Px activity in the serum of patients with MS $(55.2 \pm 16.2 \mu \mathrm{g} / \mathrm{L}, 6676.1 \pm 2386.4 \mathrm{U} / \mathrm{L}$; respectively) were significantly lower $(\mathrm{p}<0.01, \mathrm{p}<0.05$, respectively) than in the control group $(79.2 \pm 20.6 \mu \mathrm{g} / \mathrm{L}$, $8029.9 \pm 2650.1 \mathrm{U} / \mathrm{L}$; respectively). We observed correlation $(\mathrm{r}=0.39, \mathrm{p}<0.01)$ between Se concentration and GSH-Px activity in the serum. The TAS in the serum of patients with MS $(1.03 \pm 0.37 \mathrm{mmol} / \mathrm{L})$ was also significantly lower $(\mathrm{p}<0.01)$ than in the healthy volunteers $(1.48 \pm 0.41 \mathrm{mmol} / \mathrm{L})$ (see Table 2$)$.

Table 3 shows the stepwise multiple linear regression analysis of the influence of frequent consumption of food products on Se concentration in the serum of patients with MS. Frequent consumption of poultry, bakery products, pulses and fish seemed to increase serum Se concentration in the group of patients; whereas frequent consumption of butter, wholegrain bread, sweet beverages and sugar was found to accompany with lower values of $\mathrm{Se}$ in the serum. The independent variables included in the model accounted for about $59 \%$ of the variance.

In the control group frequent consumption of offal, milk, beer, bakery products and fruit seemed to increase Se concentration in the serum; while frequent eating of sausages and vegetable oil was found to accompany with lower values of Se in the serum. The independent variables included in the model accounted for about $67 \%$ of the variance (see Table 4).

We have observed significantly lower TAS $(\mathrm{p}<0.05$, $\mathrm{p}<0.01$; respectively) in the serum of smokers and those patients who received immunomodulatory drugs $(0.95 \pm 0.39 \mathrm{mmol} / \mathrm{L}, 0.92 \pm 0.34 \mathrm{mmol} / \mathrm{L}$; respectively $)$ compared to no-smoking patients and not taking immunomodulators $(1.14 \pm 0.33 \mathrm{mmol} / \mathrm{L}, 1.31 \pm 0.31 \mathrm{mmol} / \mathrm{L}$; respectively).

\section{Discussion}

Free radical attack has been linked to numerous pathological conditions such as inflammation and infections in all organs of the body. Reactive oxygen species are generated endogenously during inflammation and lipid peroxidation. Low antioxidant level affects the immune system. Oxidative stress is an important factor involved in the pathogenesis of MS, including speeding up the production of reactive oxygen species [11-13]. Both

Table 2 Content of Se, GSH-Px activity and TAS in the serum of patients with multiple sclerosis (MS) and in the control group

\begin{tabular}{|c|c|c|c|c|c|c|}
\hline & \multicolumn{2}{|c|}{ Selenium $(\mu \mathrm{g} / \mathrm{L})$} & \multicolumn{2}{|c|}{ GSH - Px (U/L) } & \multicolumn{2}{|c|}{ TAS (mmol/L) } \\
\hline & $\begin{array}{l}\text { Control group } \\
\text { mean } \pm \text { SD } \\
\text { (n) }\end{array}$ & $\begin{array}{l}\text { MS patients } \\
\text { mean } \pm \text { SD } \\
\text { (n) }\end{array}$ & $\begin{array}{l}\text { Control group } \\
\text { mean } \pm \text { SD } \\
\text { (n) }\end{array}$ & $\begin{array}{c}\text { MS patients } \\
\text { mean } \pm \text { SD } \\
\text { (n) }\end{array}$ & $\begin{array}{l}\text { Control group } \\
\text { mean } \pm \text { SD } \\
\text { (n) }\end{array}$ & $\begin{array}{c}\text { MS patients } \\
\text { mean } \pm \text { SD } \\
\text { (n) }\end{array}$ \\
\hline \multirow{2}{*}{ All subject } & $79.2 \pm 20.6$ & $55.2^{\#} \pm 16.2$ & $8029.9 \pm 2650.1$ & $6676.1^{*} \pm 2386.4$ & $1.48 \pm 0.41$ & $1.03^{\#} \pm 0.37$ \\
\hline & (63) & (101) & (63) & (101) & (63) & (101) \\
\hline \multirow{2}{*}{ A) Smoking } & $87.6 \pm 24.4$ & $54.9 \pm 16.2$ & $8548.4 \pm 2221.5$ & $6649.6 \pm 2421.0$ & $1.38 \pm 0.31$ & $0.95^{* \mathbf{A} / \mathbf{B}_{ \pm}} 0.39$ \\
\hline & (26) & (45) & (26) & (45) & (26) & (45) \\
\hline \multirow{2}{*}{ B) No-smoking } & $79.4 \pm 17.52$ & $55.6 \pm 13.5$ & $8536.1 \pm 2919.6$ & $6609.2 \pm 1948.4$ & $1.31 \pm 0.41$ & $1.14 \pm 0.33$ \\
\hline & (37) & (56) & (37) & (56) & (37) & (56) \\
\hline \multirow{2}{*}{ C) Taking ID } & \multirow{2}{*}{ - } & $55.4 \pm 17.8$ & & $6911.9 \pm 2480.9$ & & $0.92^{\# \mathbf{C} / \mathbf{D}_{ \pm}} 0.34$ \\
\hline & & (52) & & (52) & & (52) \\
\hline \multirow{2}{*}{ D) No-taking ID } & \multirow{2}{*}{ - } & $58.6 \pm 14.8$ & & $6684.5 \pm 2433.1$ & & $1.31 \pm 0.31$ \\
\hline & & (49) & & (49) & & (49) \\
\hline
\end{tabular}


Table 3 Stepwise multiple linear regression analysis of influence of frequency consumption of food products on content of Se in serum of patients with MS, $\beta$ coefficients and significance of variables entered in the model

\begin{tabular}{lccc}
\hline $\begin{array}{l}\text { Independent } \\
\text { variables }\end{array}$ & $\boldsymbol{\beta}$ coefficient (SE) & Significance level & Model $\mathbf{R}^{2}$ \\
\hline Poultry & $0.520(0.127)$ & 0.0004 & \\
Bakery products & $0.533(0.137)$ & 0.0006 & \\
White bread & $0.687(0.189)$ & 0.0012 & \\
Pulses & $0.326(0.115)$ & 0.0087 & \\
Fish & $0.352(0.134)$ & 0.0142 & 0.59 \\
Butter & $-0.652(0.178)$ & 0.0011 & \\
Wholegrain bread & $-0.302(0.115)$ & 0.0143 & \\
Sweet beverages & $-0.262(0.126)$ & 0.0461 & \\
Sugar & $-0.267(0.134)$ & 0.0573 & \\
\hline
\end{tabular}

$\mathrm{SE}$ - standard error.

demyelination and inflammation are linked with the generation of reactive oxygen species. Factor facilitating the activation of oxidative process induced by reactive oxygen species is an increased demand for oxygen by neurons in the central nervous system and decreased concentrations of endogenous antioxidants and other compounds that can inactivate free radicals [12]. Se is an active component of various enzymes involved in redox reactions which protect membranes from oxidative damage. Deficit of selenium is one of the risk factors that may predispose to inflammatory diseases [14]. Dietary Se, mainly through its incorporation into selenoproteins, plays an important role in inflammation and immunity processes so, appropriate concentration of Se is important for immunity but it also helps in regulation of excessive immune responses and chronic inflammation [15].

The reference level of Se in the serum is $70-140 \mu \mathrm{g} / \mathrm{L}$ [16] and the reference range of GSH-Px is 4171 - 10881 U/L [17]. We observed decreased Se concentration in the

Table 4 Stepwise multiple linear regression analysis of influence of frequency consumption of food products on content of Se in serum of control group, $\beta$ coefficients and significance of variables entered in the model

\begin{tabular}{lccc}
\hline $\begin{array}{l}\text { Independent } \\
\text { variables }\end{array}$ & $\boldsymbol{\beta}$ coefficient (SE) & Significance level & Model $\mathbf{R}^{2}$ \\
\hline Offal & $0.393(0.100)$ & 0.0005 & \\
Milk & $0.347(0.101)$ & 0.0017 & \\
Beer & $0.250(0.097)$ & 0.0151 & \\
Bakery products & $0.323(0.132)$ & 0.0203 & 0.67 \\
Fruit & $0.245(0.115)$ & 0.0419 & \\
Sausages & $-0.352(0.112)$ & 0.0039 & \\
Vegetable oil & $-0.396(0.128)$ & 0.0044 & \\
\hline
\end{tabular}

SE - standard error. serum of the examined patients with MS, whereas the average level of Se was within the reference range in the control group. Serum concentration of TAS in patients with MS was also below the references ranges for European population $(1.30-1.77 \mathrm{mmol} / \mathrm{L})$ [17].

So far, the concentration of Se, GSH-Px activity and TAS in the serum of patients with MS have not been estimated in the north-eastern region of Poland. Similar results for the decreased Se concentration in Mongolian patients with MS obtained Komatsu et al. [18]. Also similar to our research, studies of Mai et al. [19] showed lower level of GSH-Px in MS patients than in healthy volunteers. Miller et al. [20] evaluated the TAS in patients with MS living in the central Poland and also found its significant reduction in comparison to the control group.

The content of Se in a diet depends on Se availability in the environment. It has been well documented that Se levels in subjects from different regions of Poland are rather low [21,22]. Our previous investigations showed that a degree ratio of realization of the recommended daily allowance for Se (60 and $70 \mu \mathrm{g} /$ day for women and men, respectively) was about $50 \%$ [23]. A stepwise multiple linear regression analysis showed that dietary habits influence on concentration of Se in the serum both in patients with MS and the control group, but other products have an impact on that status, which may result from differences in the diet of the study groups. An analysis of the frequency distribution of consumption in individual food groups, indicated that diet differs between the patients with MS and the healthy subjects. People with MS more often consumed processed products such as canned meat and canned fish, margarine, sweetened beverages, jam and sugar, while those in the control group frequently consumed products such as fish, fruits, vegetables, legumes. According to the food pyramid, cereals which form the basis were consumed with similar frequency in both groups. Certain cereal products and vegetables are also known to deliver a significant amount of Se to the organism. Among Spanish population levels of Se were positively correlated with the consumption of fruit and vegetables [24]. Among the food stuffs high content of Se is in Brasil nuts, fish, kidney, liver, chicken, eggs and bean $[24,25]$. Wholegrain cereals, despite the high mineral content, have a lower bioavailability due to a competition between mineral elements in the stage of absorption in the gastrointestinal tract. Additionally, the presence of dietary fiber has a negative impact on bioavailability [26]. In our region, meat products can be a main source of Se in diets. Our earlier study of food products from the Podlasie region showed that meat, especially poultry and offal, are the best source of Se in diets $[24,27]$. Our earlier research showed that meat products can provide on average about $24 \%$ general content of Se in 
diet [28]. Milk products are rather poor source of Se in our region, but it is considered that Se derived from high protein products has a good bioavailability $[29,30]$. Our research showed that consumption of sugar and sweet beverages may decrease the serum level of Se. Refined sugar is devoid of minerals, and it is considered that sugar can leach minerals from the body [31]. That explains in a part the results of our work on the influence of dietary habits on serum Se concentration of the patients with MS.

\section{Conclusions}

Serum Se concentration, GSH-Px activity and TAS value were significantly lower in patients with relapsingremitting MS compared with healthy volunteers. Dietary habits have a significant influence on Se status. Smoking cigarettes and intake of immunomodulatory drugs therapy have a negative impact on TAS of examined patients.

\section{Competing interests}

The authors declare that they have no competing interests.

\section{Authors' contributions}

KS participated in writing the manuscript, designing the study and took part in the experiments procedures. JK collected the samples and diet questionnaires and took part in clinical consultation. EK estimated samples, performed the statistical analysis and assisted in writing the manuscript. JS estimated samples. MJ and ZM participated in the design of the study and took part in clinical consultation. MHB participated in study coordination and in manuscript preparation. All authors read and approved the final manuscript.

\section{Authors' information}

Elżbieta Karpińska who "Studies, research, commercialization - a support programme of UMB doctoral students" Sub-measure 8.2.1 Human Capital Operational Programme, co-financed from the European Union under the European Social Fund.

\section{Acknowledgments}

This study was conducted with the use of equipment purchased by Medical University of Białystok as part of the OP DEP 2007-2013, Priority Axis I.3, contract No. POPW.01.03.00-20-022/09. Presented work was financially supported by the Polish Ministry of Science and Higher Education (grant no 123-16874 F).

\section{Author details}

'Department of Bromatology, Medical University of Bialystok, Mickiewicza 2D St, Bialystok 15-222, Poland. 'Department of Neurosurgery and Invasive Neurology, Medical University of Bialystok, Bialystok, Poland. ${ }^{3}$ NZOZ Kendron, Bialystok, Poland.

Received: 7 March 2014 Accepted: 11 June 2014

Published: 18 June 2014

\section{References}

1. Leary S, Porter B, Thompson A: Multiple sclerosis: diagnosis and the management of acute relapses. Postgrad Med J 2005, 81:302-308.

2. Haider L, Fischer MT, Frischer JM, Bauer J, Höftberger R, Botond G, Esterbauer $\mathrm{H}$, Binder $\mathrm{CJ}$, Witztum $\mathrm{L}$, Lassmann H: Oxidative damage in multiple sclerosis lesions. Brain 2011, 134:1914-1924.

3. Stachowiak J: Can diet help multiple sclerosis? [http://ms.about.com/b/2009/ 03/19/can-diet-help-multiple-sclerosis.htm]

4. Riccio P, Rossano R, Liuzzi GM: May diet and dietary supplements improve the wellness of multiple sclerosis patients? A molecular approach. Autoimmune Dis 2010, 2010:249842.
5. Wesołowski M, Ulewicz B: Selen - pierwiastek śladowy niezbędny dla człowieka - występowanie, znaczenie biologiczne i toksyczność (in Polish). Farm Pol 2000, 56:1004-1019.

6. Zachara BA, Pawluk H, Bloch-Bogusławska E, Śliwka KM, Korenkiewicz J, Skok Z, Ryc K: Tissue level, distribution, and total body selenium content in healthy and diseased humans in Poland. Arch Environ Health 2001, 56:461-466.

7. Miller NJ, Rice-Evans C, Davies MJ, Gopinathan V, Milner A: A novel method for measuring antioxidant capacity and its application to monitoring the antioxidant status in premature neonates. Clin Sci 1993, 84:407-412.

8. McDonald WI, Compston A, Edan G, Goodkin D, Hartung HP, Lublin FD, McFarland HF, Paty DW, Polman CH, Reingold SC, Sandberg-Wollheim M, Sibley W, Thompson A, van den Noort S, Weinshenker BY, Wolinsky JS: Recommended diagnostic criteria for multiple sclerosis: guidelines from the International Panel on the Diagnosis of Multiple Sclerosis. Ann Neurol 2001, 50:121-127.

9. Polman CH, Reingold SC, Edan G, Filippi M, Hartung HP, Kappos L, Lublin FD, Metz LM, McFarland HF, O'Connor PW, Sandberg-Wollheim M, Thompson AJ, Weinshenker BG, Wolinsky JS: Diagnostic criteria for multiple sclerosis: 2005 revisions to the "McDonald Criteria". Ann Neurol 2005, 58:840-846.

10. Gronowska-Senger A: Przewodnik metodyczny badań sposobu żywienia (in Polish). Warsaw: Committee of Human Nutrition Science, Polish Academy of Sciences; 2013.

11. Comoglu S, Okcu Z: Serum levels of antioxidant vitamins and lipid peroxidation in MS. Nutr Neurosci 2002, 5:215-220.

12. Gilgun-Sherki Y, Melamed E, Offen D: The role of oxidative stress in the pathogenesis of multiple sclerosis: the need for effective antioxidant therapy. J Neurol 2004, 251:261-268.

13. Koch M, Mosteret J, Arutjungan A, Stepanov M: Plasma lipid peroxidation and progression of disability in multiple sclerosis. Eur J Neurol 2007, 14:529-533.

14. Rayman MP: The importance of selenium to human health. Lancet 2000, 356:233-234.

15. Huang Z, Rose AH, Hoffmann PR: The role of selenium in inflammation and immunity: from molecular mechanisms to therapeutic opportunities. Antioxid Redox Signal 2012, 16:705-743.

16. Neumeister B, Besenthal I, Bohm BO: Klinikleitfaden Labordiagnostik. Munchen: Elselvier Urban \& Fisher Verlag; 2013.

17. Applications Randox Laboratories Ltd. UK: [www.randox.com]

18. Komatsu F, Kagawa Y, Kawabata T, Kaneko Y, Kudoh H, Purvee B, Otgon J, Chimedregzen U: Influence of essential trace minerals and micronutrient insufficiencies on harmful metal overload in a Mongolian patient with multiple sclerosis. Curr Aging Sci 2012, 5:112-125.

19. Mai J, Sørensen PS, Hansen JC: High dose antioxidant supplementation to MS patients. Effects on glutathione peroxidase, clinical safety, and absorption of selenium. Biol Trace Elem Res 1990, 24:109-117.

20. Miller E, Mrowicka M, Malinowska K, Zołyński K, Kedziora J: Effects of the whole-body cryotherapy on a total antioxidative status and activities of some antioxidative enzymes in blood of patients with multiple sclerosispreliminary study. J Med Invest 2010, 57:168-173.

21. Church S: The UK total diet study and 1995 selenium intake. J Food Compos Anal 2000, 13:557-559.

22. Wasowicz W, Gromadzińska J, Rydzyński K, Tomczak J: Selenium status of low-selenium area residents: Polish experience. Toxicol Lett 2003, 137:95-101

23. Sánchez C, López-Jurado M, Aranda P, Llopis J: Plasma levels of copper, manganese and selenium in an adult population in southern Spain Influence of age, obesity and lifestyle factors. Sci Total Environ 2010, 408:1014-1020.

24. Borawska MH, Markiewicz R, Socha K: The content of selenium in breed and game liver. Pol J Hum Nutr Metab 2005, 32:227-230.

25. Chang JC, Gutenmann WH, Reid CM, Lisk DJ: Selenium content of Brazil nuts from two geographic locations in Brazil. Chemosphere 1995, 30:801-802.

26. Greger JL: Nondigestible carbohydrates and mineral bioavailability. J Nutr 1999, 129:1434S-1435S.

27. Markiewicz R, Borawska MH: Meat as a source of selenium in the diet of the inhabitants of Podlasie Region (in Polish). Bromat Chem Toksykol 2005, 38:249-252. 
28. Markiewicz R, Socha K, Borawska MH, Gutowska A: Selenium in diets and serum of eldery people from north-eastern region of Poland. Fres Environ Bull 2010, 19:372-377.

29. Markiewicz R, Borawska MH, Jakimik AE: Evaluation of cow milk from Podlasie province as selenium source in diet (in Polish). Bromat Chem Toksykol 2005, 38:245-248.

30. Chen J, Lindmark-Månsson H, Drevelius M, Tidehag P, Hallmans G, Hertervig E, Nilsson A, Akesson B: Bioavailability of selenium from bovine milk as assessed in subjects with ileostomy. Eur J Clin Nutr 2004, 58:350-355.

31. Why sugar is toxic to the body. [http://www.globalhealingcenter.com/sugarproblem/refined-sugar-the-sweetest-poison-of-all]

Cite this article as: Socha et al:: Dietary habits and selenium, glutathione peroxidase and total antioxidant status in the serum of patients with relapsing-remitting multiple sclerosis. Nutrition Journal 2014 13:62.

\section{Submit your next manuscript to BioMed Central and take full advantage of:}

- Convenient online submission

- Thorough peer review

- No space constraints or color figure charges

- Immediate publication on acceptance

- Inclusion in PubMed, CAS, Scopus and Google Scholar

- Research which is freely available for redistribution 